\title{
Remote Sensing Based Study of Surge Characterization of Klutlan and Fisher Glaciers, St. Elias Mountains, North America
}

\section{Arjun Pratap Shahi}

Independent Researcher

Praveen Kumar Rai ( $\nabla$ rai.vns82@gmail.com )

Khwaja Moinuddin Chishti Language University

Prafull Singh

Central University of South Bihar

Varun Narayan Mishra

Suresh Gyan Vihar University

\section{Research Article}

Keywords: Glacier Surging, DEM differencing, Image correlation, Yukon, Alaska.

Posted Date: August 4th, 2021

DOI: https://doi.org/10.21203/rs.3.rs-615411/v1

License: (c) (i) This work is licensed under a Creative Commons Attribution 4.0 International License. Read Full License 


\section{Abstract}

The detailed study of glacier surges in St. Elias Mountains is very scarce.Robust and repeat observation of surface displacement, elevation changes and surge reoccurrence intervalsare limited to few surge-type glaciers (e.g., Variegated, Bearing, Lowell and Donjek). Therefore, this study presents the first detailed surge dynamics of Klutlan (1990-2019) and Fisher (1984-2019) glaciers in the St. Elias Mountains, North America. Surface displacement estimation using optical imagery (Landsat TM, ETM+, OLI and Sentinel 2) and surface elevation changes derived from ASTER DEMs were used to understand the surge dynamics. Klutlan Glacier lackspre-surge acceleration and had six years longactive phase (2013-2019). The surge of Klutlan Glacier showed two surface flow maxima(6.2 $\pm 0.2 \mathrm{~m} \mathrm{~d}^{-1}$ and $\left.\sim 5 \pm 0.2 \mathrm{~m} \mathrm{~d}^{-1}\right)$,in summer of 2016 and2018 respectively.During 2019-2020, in the reservoir zone, maximum surface lowering of $-65 \pm 33 \mathrm{~m}$ was observed whereas, in the receiving zone, maximum ice thickness increased by $+31 \pm 40 \mathrm{~m}$. The dynamic balance line (DBL)on Klutlan Glaciermoved 16 km down-glacier during 2019 (788masl.) in comparison with 2004 (1998 masl.). The Fisher Glacier exhibitssix years (2007-2013) long pre-surge acceleration, three years (2013-2016) long active phase and surge terminated gradually. The peak surge displacement $\sim 7 \pm 0.4 \mathrm{~m} \mathrm{~d}^{-1}$ was observed in summer of 2015 . The reservoir zone experienced a maximum lowering of $-60 \pm 22$ mfrom 2019 to 2003 while lower receiving zone maximum thickened by $+80 \pm 22 \mathrm{~m}$. The DBL shifted $\sim 3 \mathrm{~km}$ down-glacier during 2019 (959 masl.) as compared to 2016 (1006 masl.). This study assumes that the surge of Fisher Glacier is partially matched with a thermally controlled surge. However, the surge characteristics of Klutlan Glacier doesnot corroborate with globally recognised hydrological or thermally controlled surge mechanism.

\section{Introduction}

Surge glacier ice velocity periodicallyswitches between long duration of slow flow (i.e., quiescent phase) and short duration of fast flow (i.e., surge or active phase)(Meier and Post, 1969; Jiskoot, 2011). During the surge phase, ice velocity increases abruptly (10-1000 times) and a large volume of ice rapidly transfers from an upper reservoir zone to alower receiving zone.This may result in a rapid advance of the glacier terminus over periods of months to years. In the quiescent phase, glacier ice usually retreats and/or stagnates in the receiving zone,whileice mass builds in the reservoir zone, and the thickening and increase in surface slope increases the basal shear stresswhich mayprecondition a subsequent surge. Some studies refer to the boundary between the reservoir and receiving zones as thedynamic balance line (DBL) where net mass change is zero(Dolgoushin and Osipova, 1975; Burgess et al., 2012; Kochtitzky et al., 2020).About $<1 \%$ of total glaciers in the world have been identified as surge-type(Jiskoot et al., 1998; Sevestre and Benn, 2015).The actual cause of glacier surging is still unknown; however, earlier studies explained surges mechanism by the two subglacial processes (1) hydrological and (2) thermal switches. The hydrological switch refers to the redistribution of the subglacial drainage system from the effective conduit to an ineffective linked-cavity system with the restructuring of subglacial drainage(Kamb et al., 1985; Kamb and Engelhardt, 1987). Conversely, thermal switch reflects the change in mainly cold-based ice in quiescence, to warm-based ice in the active phase(Fowler et al., 2001; Murray et al., 2003). The 
hydrological switch is largely associated with Alaskan-type glaciers whereas a thermal switch is generallyreported in the Svalbard region. However, recent attempts have been made to combine hydrological and thermal subglacial processes into a single unified model of enthalpy cycle where the quasiperiodic oscillation of velocity between long duration of slow flow and short duration of fast flow has been related to an imbalance between enthalpy gain and loss(Sevestre and Benn, 2015; Benn et al., 2019).

The St. Elias Mountain range is located at the border of Alaska, USA and Yukon, Canada, holds a third largest cluster of surge-type glaciers(Post, 1969; Clarke et al., 1986; Sevestre and Benn, 2015; Kochtitzky et al., 2020). However, only a fewsurge-type glaciers (e.g., Variegated, Bering, Lowell and Donjek) have been studied to understand surge dynamics using elevation change and surface displacement observations(Kamb et al., 1985; Kamb and Engelhardt, 1987; Fatland and Lingle, 2002; Burgess et al., 2012; Bevington and Copland, 2014; Kochtitzky et al., 2019).The monitoring of these surge-type glaciers is very essential as they have blocked regional drainage and created a hazardous situation for downstream areas. Lowell Glacier has repeatedly ceased the flow of Alsek river and created Alsek lake several times in past 1000 years(Clague and Rampton, 1982; Clarke and Holdsworth, 2002; Bevington and Copland, 2014). Also, previous surges of Klutlan Glacier have impeded the flow of Generec river and formed two ice-dammed lakes with estimated volumes of $>10^{8} \mathrm{~m}^{3}$, which might have caused devastation in Generec river valley after the outburst floods.

In-situ observations are important to understand surge mechanisms. The englacial and subglacial processes and conditions are crucial (e.g., distribution and quantity of debris and water)to comprehend the surge mechanism. However, this information is scarce or unknown in the St. Elias Mountain range, asfieldobservationsarehard toobtain. In such case, long-term glacier surface displacementand elevation change mapsderived from multiple satellite images and DEMs can provide an enormousunderstanding of mass transfer from 'reservoir' to 'receiving' zones. Many studies in the St. Elias Mountain range and surrounding areas have usedtemporal satellite images and DEMs to investigate glacier surge dynamics(Bevington and Copland, 2014; Kochtitzky et al., 2019; Fu and Zhou, 2020). Recently, Altena et al., (2019)reported surge processof Fisher and Klutlan glaciers based on surface velocity derived from the Global Land Ice Velocity Extraction (GoLIVE; cell size $300 \mathrm{~m}$ )from Landsat 8 data. However, due to cloud cover, shadow and snow conditions, this coarse resolution data $(\sim 300 \mathrm{~m})$ may be unsuccessful to trackrapid change in surface velocity (i.e., acceleration and deceleration), which is important to understand the surge mechanism. Thus, the main goal of the present study is to improve the understanding of recent surge evolution of KlutlanandFisherglaciersusing automated feature tracking and elevation change. We have also compared the results of these glaciers with other surges in Alaskaand Svalbard.

\section{Study Area And Surge History}

The St Elias Mountains straddle the international border between Alaska, USA and Yukon, Canada andis one of the heavily glacierized regions in the world. The total ice-covered area of St Elias Mountains is 
$33174 \mathrm{~km}^{2}$ (RGI Consortium, 2017). Due to its close proximity tothe Gulf of Alaska and its high relief within few kilometers from the coast, the St Elias Mountainsaccommodates ahigh concentration of varied surge-type glaciers (counts 322 ) includingsmall and large temperate and polythermal glaciers, as well as tidewater and land or lake-terminating glaciers(Clarke and Holdsworth, 2002; Sevestre and Benn, 2015; Kochtitzky et al., 2019). All the glaciers in this region are located on rugged, mountainous terrain and rock type varies greatly from region to region(Post, 1969; Crompton et al., 2018). The St Elias Mountain range acts as a topographic, climatic and hydrological dividebetween the coastal (W) and continental $(E)$ sides of the region. Therefore, glaciers facing Gulf of Alaska experience moist and humid climate which creates a strong gradient in precipitation, with general high accumulation rates on temperature glaciers(Fleming et al., 2000; Clarke and Holdsworth, 2002). Conversely, glaciers on the continental side experience a colder and drier climate and can be polythermal(Marcus and Ragle, 1970; Waechter, 2013).We selected two glaciers, the Klutlan andthe Fisher glacier, for the present studyas best of our knowledge there is no literature available which studied surge mechanism of these glaciers using combined analysis ofice flow and elevation change.

Klutlan Glacier $\left(61.39^{\circ} \mathrm{N}, 141.09^{\circ} \mathrm{W}\right)$ originates from Mount Bona, Icefield range of Alaska (4958 $\mathrm{m}$ a.s.I.) and terminates (1122 $\mathrm{m}$ a.s.l.) in Yukon, Canada(Figure 1a). Klutlan Glacier (80.4 km) is the largest valley glacier of White River drainage basin and covers an area of $957.8 \mathrm{~km}^{2}$ (RGI Consortium, 2017). It flows eastward for $55 \mathrm{~km}$ and turns northward for $25 \mathrm{~km}$. The three major tributaries of Klutlan Glacier which join the main trunk from the south side are Nesham, Mount Wood and Brabazon glaciers (Figure 1a). Of these, Nesham and Mount Wood glaciers are surge-type tributaries and Brabazon Glacier is a non-surging tributary (DriscollJr, 1980; Clarke and Holdsworth, 2002).Theearliest recorded surge of Klutlan Glacier began during 1961 andoriginated $20 \mathrm{~km}$ up-glacier from the mouth of Nesham valley (DriscollJr, 1980). The Nesham Glacier surge also started in 1961 and terminated before August 1963 (Post, 1969). In 1977, the entireKlutlan Glacier system was in quiescence (Clarke and Holdsworth, 2002)and remained so until 2012 (Waechter, 2013). The proglacial region of Klutlan Glacier is characterized by a complex ofneoglacial ice-cored terminal moraines(DriscollJr, 1980) (Figure 1a). A study conducted by Rampton (1970) on these moraines suggests that thisglacier system is subjected to repeat surge as its oldest

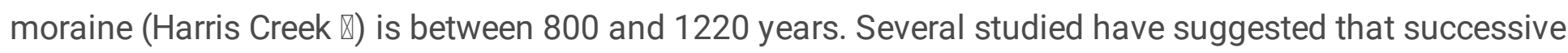
surges of Klutlan Glacier (interval of $\sim 80$ years) had carried Nesham surge lobes at the terminus as a discrete geomorphic feature (K囚-K囚moraine) (DriscollJr, 1980).

Fisher Glacier $\left(60.06^{\circ} \mathrm{N}, 138.58^{\circ} \mathrm{W}\right)$ is the third-largest (length $\left.48 \mathrm{~km}\right)$ surge-type glacierof in the Alsek river system, which also include the Dusty $(38 \mathrm{~km})$, Lowell $(70 \mathrm{~km})$ and Tweedsmuir(70 km) glaciers (Clarke and Holdsworth, 2002). Fisher Glacier covers an area of $396.1 \mathrm{~km}^{2}$, flows eastward from an elevation of $4567 \mathrm{~m}$ a.s.l. and drains directly into Alsek river, terminating at $417 \mathrm{~m}$ a.s.l. (Figure $1 \mathrm{~b}$ )(RGI Consortium, 2017). Fisher Glacier surged in 1970 (Clarke and Holdsworth, 2002). However,littleinformation is available on the surge mechanism or surge development of Fisher Glacier (e.g., Clarke and Holdsworth, 2002; Waechter, 2013). 


\section{Methodology}

\subsection{Data Sources}

To understand the temporal evolution of surface velocity on Fisher and Klutlan glaciers we used 131satellite images from the longest Landsat program (sensors MSS, TM, ETM+ and OLI) available since 1972.In addition, 14Sentinel 2A images were used to track the surface velocity ofFisher Glacier between 2016 and 2019, during which seasonal snow and cloud cover made the use of Landsat imagesnot feasible.All Landsat and Sentinelimages(TablesS1, S2 and S3)were obtained from the United States Geological Survey (USGS; http://earthexplorer.usgs.gov/).Landsat and Sentinel images with limited snow and cloud cover, mainly betweenearly June andlate October,were used for feature tracking. A total of 24 stereoASTERimages(Table S7) were used to generate DEMs to measureelevation changes on Fisher and Klutlan glaciers. These ASTER imageswere obtained from theNASA EARTH SCIENCE DATA (https://search.earthdata.nasa.gov/)under the flagship of the Global Land Ice Measurement from Space program(Kargel et al., 2005). The glacier outlineswere acquired from the Randolph Glacier Inventory (RGI 6.0) in a polygonshapefile format to extract the surface displacement and elevation change information of Fisher and Klutlan glaciers (RGI Consortium, 2017).They were improved by manual digitization using visual interpretation of 2019 Landsat image.

\subsection{Surface velocity estimation}

Normalised Cross-Correlation (NCC), an automated feature tracking method, was used to determine surface displacement from two sequentialLandsat or Sentinel images within theimage correlation software CIAS (KääbandVollmer, 2000; Heid and Kääb, 2012; Redpath et al., 2013). Phase correlation was used to determine vertical surface displacement between two orthorectified satellite images within the software packageCOSI-Corr(Leprince et al., 2007). We used a range insearch window size from $10 \times 10$ to 190×190in CIAS, and a 10×10 reference window size to estimate the displacement of glacier surface features. We generated 28 and 15 surface displacement maps using CIAS software for Klutlan and Fisher glaciers, respectively (Figures S3, S4 and S5). The anomalousvalues of surface displacements were removed using several filters (Scherler et al., 2008; Redpath et al., 2013; Quincey et al., 2015). First, crosscorrelation values $\leq 0.6$ were removed as suggested by Redpath et al., (2013), and then a direction filter was used to exclude velocity vectors outside $\pm 45^{\circ}$ of the central flow line direction. We further used the frequency correlator engine with varying window size ranging from $32 \times 32$ to $256 \times 256$ and a step size of 4 pixels. When the surface displacements were too large, the correlation window was extended by up to 256 pixels. After determining displacement fields (north-south and east-west) and a signal-to-noise ratio, a Non-Local Mean filter was applied with the noise parameter $\mathrm{H} \geq 0.95$ to reduce noise (Buades et al., 2006; Goossens et al., 2008). Outliers orvalues with a weak SNR in a correlation file from each band were removed by using the discard tool. Atotal of 111 and 50 correlation image pairs generated with varying window size for Fisher and Klutlan glaciers, respectively. All the corrected surface velocity data were then converted to a daily scale and graphs of surface velocities were created along the manually digitized centre flow line of each glacier (Fig 1). 


\subsection{Generation and correction of DEMsand elevation changes}

Previousstudies have used ASTER DEMs to extract elevation change insurging glaciers, sometimes in combination with other DEMs(Pitte et al., 2016; Kochtitzky et al., 2019). We used band 3N and 3B of each ASTER (AST_L1A product) images for the generation of DEMs without any ground control points (GCPs) as suggested byBhambri et al., (2019)using ERDAS Imagine Photogrammetry Suite 2015. The planimetric shift may lead to systematic biases in elevation difference maps (Nuth and Kääb, 2011; Gardelle et al., 2013) (Figure S1). Therefore, the universal co-registration method proposed by Nuth and Kääb (2011) was used to correct the planimetric shift in ASTER DEMs. Since SRTM DEM is not available for the study area, 2019 and 2018 ASTER DEMs were used as reference DEM to co-register other ASTER DEMs for Fisher and Klutlan glaciers, respectively.A maximum of five iterations were performed to attain minimal $(<1 \mathrm{~m})$ planimetric shift in each ASTER DEM. The outliers were removed using elevation range from -150 to +150 (Figure S2). Six and sevenelevation difference maps were created using planimetrically corrected ASTER DEMs for Fisher and Klutlan glaciers, respectively.

\subsection{Terminus position change}

Glacier length change of Fisher Glacier was determined by manually digitizing the terminus positionfrom the available Landsat and Sentinel images,and applying a glacier length tool developed for the ArcGIS software(Bjørk et al., 2012).As this tool only uses the snout of the glacier as input, we digitised these from the Landsat and Sentinel satellite images, not the entire glacier boundary.

\subsection{Uncertainty assessment}

Uncertainty in glacier velocity was calculated using.

\section{(Cpix + Cmatch) $\Delta \mathrm{x} \Delta$ ?}

where $\mathrm{C}_{\text {pix }}$ and $\mathrm{C}_{\text {match }}$ areuncertainties in pixels $(\mathrm{p})$ in matching algorithm and co-registration, respectively, $\Delta \mathrm{x}$ is the image resolution in meters and $\Delta \mathrm{t}$ is the time interval between the successive image pairs in days(Quincey et al., 2015).A $0.5 \mathrm{p}$ value is considered for both $\mathrm{C}_{\text {pix }}$ and $\mathrm{C}_{\text {match }}$ as suggested by Quincey et al., (2015) and Bhambri et al., (2017).

The uncertainty in frontal change was estimated using the following equation proposed by Hall et al., (2003).

where $\mathrm{e}$ is the error in frontal change, $\mathrm{x} 1$ is thepixel resolution of imagery $1, \mathrm{x} 2$ is thepixel resolution of imagery 2, and Ereg is thehorizontal shift between two images.

The uncertainty in glacier surface elevation change is estimated based on non-glacierized area. The standard deviation (SD) of the non-glacierized area is used as a standard statistical estimator for 
determination of uncertainty in surface elevation (e.g., Pitte et al., 2016) (Table S5 \& Table S6).

\section{Results}

\subsection{Klutlan Glacier}

\subsubsection{Surface displacement}

During the study, 41 and 28 surface displacement maps of Klutlan Glacier were produced from 1990 to 2019 using COSI-Corr and CIAS software (Figure 3-6; Figures S3 and S4) respectively. Between 1990 and 1998 , the maximum surface displacement was $0.4 \pm 0.03 \mathrm{~m} \mathrm{~d}^{-1}$ in the upper reservoir zone (43 $\mathrm{km}$ upglacier from terminus) and less than $0.1 \pm 0.05 \mathrm{~m} \mathrm{~d}^{-1}$ in the from terminus to $\sim 25 \mathrm{~km}$ up-glacier the maximum surface displacement remained. However, during 1996-1997 surface displacement increased slightly $\left(0.3 \pm 0.04 \mathrm{~m} \mathrm{~d}^{-1}\right), \sim 30 \mathrm{~km}$ up-glacier from terminus (Figure 2a). Between1 July 1998 and 5 August 2002, no change was observed in surface displacement $\left(0.4 \pm 0.03 \mathrm{~m} \mathrm{~d}^{-1}\right)$ in the upper reservoir zone (Figure 2b).

Between 5 August 2002 and23 July 2006, the surface displacement increased from 0.4 to $0.5 \pm 0.04 \mathrm{~m} \mathrm{~d}^{-}$ ${ }^{1}$ between $\sim 35-40 \mathrm{~km}$ up-glacier from the terminus (Figure 2c). The surface displacement profile steepened and became slightlyconvexbetween $25 \mathrm{~km}$ and $50 \mathrm{~km}$ up-glacier from terminus during 20022007 in comparison with 1999-2002 (Figure 2b \& c). The steepening of the surface displacement profile can be attributedto mass accumulation in the reservoir zone, which leads to an increase in the basal shear stress (Dolgoushin and Osipova, 1975; Jiskoot, 2011). Between2007 to 2011 the surface flow speedwas 0.3-0.4 $\pm 0.04 \mathrm{~m} \mathrm{~d}^{-1}$ at $\sim 35 \mathrm{~km}$ up-glacier from the terminus (Figure 2dand 5a) and between 2011 and 2013, the flow speed increased to $0.6 \pm 0.02 \mathrm{~m} \mathrm{~d}^{-1}$ between $25-45 \mathrm{~km}$ up-glacier from the terminus. However, the surface flow speed near the glacier terminusremained consistently low during these six years $\left(\sim 0.05 \pm 0.02 \mathrm{~m} \mathrm{~d}^{-1}\right)$ (Figure $\left.2 \mathrm{~d}\right)$.

The increase in surface speed(maximum $0.95 \pm 0.02 \mathrm{~m} \mathrm{~d}^{-1}$ ) continued in 2013-2014, between 25 and 35 km up-glacier from the terminus. Between21 August 2014 to08 August 2015, the maximum surface speeddoubled to $2.1 \pm 0.02 \mathrm{~m} \mathrm{~d}^{-1}$ (Figures3a and 5c) and between 2015 and 2016, the maximum surface displacement increased further to $3.6 \pm 0.02 \mathrm{~m} \mathrm{~d}^{-1}, \sim 15 \mathrm{~km}$ up-glacier from terminus (Figure 3b and $5 \mathrm{~d}$ ). The first maximum surface displacement(surge peak6.2 $\pm 0.14 \mathrm{~m} \mathrm{~d}^{-1}$ ) observed between 15 May and 09 July 2016, at $\sim 15 \mathrm{~km}$ from terminus (Figure 4). However, the maximum surface displacement decreased $\left(2 \pm 0.23 \mathrm{~m} \mathrm{~d}^{-1}\right)$ gradually in July to October 2016 (Figure 3c).

The high flow speed continued untilJuly 2018. Between 18 June and 6 August 2017, the maximum surface displacement again increased $\left(4.5 \pm 0.1 \mathrm{~m} \mathrm{~d}^{-1}\right), \sim 25 \mathrm{~km}$ up-glacier from terminus (Figure $3 \mathrm{~d}$ ). and between 22 June and 24 July 2018 we observed a second peak in flow speed $\left(\sim 5 \pm 0.23 \mathrm{~m} \mathrm{~d}^{-1}\right)$ near theterminus (Figure 4). The surge front reached the terminus inthis period and the surge continued until 
October 2018 with slow speed $\left(\sim 1 \pm 0.3 \mathrm{~m} \mathrm{~d}^{-1}\right)$ (Figure 3d). During 03 August to09 September 2019, the maximum surface displacement decreased gradually $\left(0.7 \pm 0.23 \mathrm{~m} \mathrm{~d}^{-1}\right) \sim 40 \mathrm{~km}$ up-glacier from terminus (Figure 3e).

\subsubsection{Elevation change}

Seven elevation change maps of Klutlan Glacier using ASTER DEMs were generated (Figure 6, 7) to understand glacier surface elevation changes before, during and after the surge. All the ASTER DEMs were subtracted from the 2002 ASTER DEM to understand the mass transfer from reservoir zone to receiving zone. The location of DBL changed frequently during the surge phase and moved significantly down-glacier from 2015 to 2019 (Figure 6 b-f). Between 2009 and 2002, the receiving zone (from 15 to 20 $\mathrm{km}$ up-glacier from terminus) maximum lowered by $-40 \pm 30 \mathrm{~m}$ and the reservoir zone (between 40 and 50 $\mathrm{km}$ up-glacier from terminus)maximum thickened by $+20 \pm 30 \mathrm{~m}$. During 2015 the DBL moved 6.1 km(1800 masl.) down-glacier in comparison to 2004 (1990 masl.). Also, lower receiving zone (up to 10 $\mathrm{km}$ up-glacier from terminus)maximum thinned by- $80 \pm 28 \mathrm{~m}$ and the surge front achieved the height of $\sim 38 \pm 28 \mathrm{~m}$ during this period, at $\sim 22 \mathrm{~km}$ up-glacier from the terminus in this period.

In 2016, the lower receiving zone (0-5 km up-glacier from terminus) exhibited maximum lowering of -70 $\pm 22 \mathrm{~m}$ whereas the surge front thickened by $+45 \pm 22 \mathrm{~m}, \sim 17 \mathrm{~km}$ up-glacier from the terminus. During 2018 , the thickened region moved down-glaciertowards terminus and the receiving zone ( $\sim 12 \mathrm{~km}$ upglacier from terminus) gainedmaximum thickening of $+52 \pm 23 \mathrm{~m}$. In 2019 , the lower receiving zone (0-5 $\mathrm{km}$ up-glacier from terminus) showeda maximum gain of $+31 \pm 40 \mathrm{~m}$ whereas the reservoir zone ( $38 \mathrm{~km}$ up-glacier from terminus) maximum thinned by $-65 \pm 33 \mathrm{~m}$. On average, in2019 the DBL shifted $\sim 16 \mathrm{~km}$ (788 masl.) down-glacier in comparison to 2004 (1990 masl.).

\subsection{Fisher Glacier}

\subsubsection{Surface displacement}

We generated42 surface displacement maps of FisherGlacier using COSI-Corr from 1984 to 2019 which covers quiescence, build-up and active phase (Figure 8-10).Also, 15 surface displacement maps of Fisher Glacier were generated using CIASbetween2000and2018to cross-check results (Supplementary Fig. S5 and S6).During 28 July 1984 to 09 September 1988, surface displacement wasslow $\left(<0.10 \pm 0.04 \mathrm{~m} \mathrm{~d}^{-1}\right)$ throughout the glacier. However, we observed a slight increase $\left(0.20 \pm 0.04 \mathrm{~m} \mathrm{~d}^{-1}\right)$ in surface displacement in upper reservoir zone (25 km up-glacier from terminus) during 09 September 1988 to 14 August 1990(Figure 8a). Between 30 June 1991 and 31 July 1999, the surface displacement gradually increased from 0.1 to $0.2 \pm 0.04 \mathrm{~m} \mathrm{~d}^{-1}$ between 25 and $30 \mathrm{~km}$ up-glacier from terminus (Figure $8 b)$. However, we did not observe any change in surface displacement $\left(0.20 \mathrm{~m} \mathrm{~d}^{-1}\right)$ in the reservoir zone ( 20 km up-glacier from terminus) between 31 July 1999 and 19 June 2007 (Figure 8c) butthisslightly increased $\left(0.2 \pm 0.04 \mathrm{~m} \mathrm{~d}^{-1}\right)$, at $\sim 12.5 \mathrm{~km}$ up-glacier from terminus during 02 July 2006 to 19 June 2007.Surface displacement profile gradually steepens along the central linebetween 1984 and 2007, 
especially in the upper reaches of the glacier (Figure 8a, 8c). Such steepening of surface displacement profile can be attributed toice mass accumulation in the reservoir zone which leads to increase inspeed of surface displacement(Dolgoushin and Osipova, 1975).

We observed the pre-surge accelerationbetween 2007 and 2013 when the maximum surface displacementincreased consistently from 0.20 to $0.40 \mathrm{~m} \mathrm{~d}^{-1}$ in upper reservoir zone ( $25 \mathrm{~km}$ up-glacier from terminus)(Figure $8 \mathrm{~d}, 10)$. Several studies have been considered such a gradual increase in surface displacement across the glacier before the main surge phase as a pre-surge acceleration. For instance, Round et al., (2017) reported about 2.5 years long pre-surge acceleration of Kyagar Glacier in the KarakoramfromSeptember 2011 to February 2014.

The maximum surface displacement doubled $\left(0.80 \mathrm{~m} \mathrm{~d}^{-1}\right)$ during 2013-2014,at $~ 15 \mathrm{~km}$ up-glacier from terminus (Figure 9a). However, we did not observe any advance in terminus till 2014. We observedan active phase in early June 2014 when maximum surface velocity reached $2.5 \pm 0.2 \mathrm{~m} \mathrm{~d}^{-1}$ (Figure 10). In the first week of August 2015, surge peak $\left(\sim 7 \pm 0.45 \mathrm{~m} \mathrm{~d}^{-1}\right)$ was observed near the glacier tongue. The surge of Fisher Glacier producedeight times acceleration in surface displacement from July 2014 and a seventeen timesacceleration since August 2013(Figure 10). However, after then the surge continued with a diminishing rate of surface displacement $\left(1.5 \pm 0.13 \mathrm{~m} \mathrm{~d}^{-1}\right)$, until 27August 2016 (Figure 9c).

Between 27 August 2016 and 08 August 2017, the surface displacementwas low $\left(\sim 0.2 \pm 0.01 \mathrm{~m} \mathrm{~d}^{-1}\right)$ and decreased further to 0.05 $0.01 \mathrm{~m} \mathrm{~d}^{-1}$ from 30 September 2017 to 03 August 2019(Figure9d, 10). Many studies also reported such slow speed $\left(0.05 \mathrm{~m} \mathrm{~d}^{-1}\right)$ of glacial surface occurred in quiescent phase (Bevington and Copland, 2014; Kochtitzky et al., 2019).

\subsubsection{Elevation change}

The six ASTER DEMs were subtracted from 2003 ASTER DEM to understand the mass transfer from the reservoir zone to the receiving zone(Figure 11). Due to limited coverage of ASTER DEMs, the DEM differencing results cover parts of Fisher Glacier but includessurface elevation changes associatedwith before, during and after the surge (Figure 12).During 2016, the reservoir zone (between 35 and $40 \mathrm{~km}$ upglacier from terminus) maximum thinned by $-67 \pm 27 \mathrm{~m}$ and the lower receiving zone ( $10 \mathrm{~km}$ up-glacier from terminus) gained maximum thickness of $+41 \pm 27 \mathrm{~m}$. In2018, the receiving zone exhibited average thickening of $+88 \pm 25$ mwhereas the surge front achieved a gain of $+110 \pm 25 \mathrm{~m}$ elevationnear the terminus. During 2019, the DBL moved 3 km (959 masl.) down-glacier in comparison to 2016 (1006 masl.) meanwhile the reservoir zone ( $\sim 35 \mathrm{~km}$ up-glacier from terminus) experienced $-60 \pm 22$ mmass loss.

\subsubsection{Terminus and frontal lakechanges}

We used the 1973 Landsat MSS image as a reference to estimate the change in glacier length of Fisher Glacier (Figure 13). The terminus of Fisher Glacier retreated $-422 \pm 121 \mathrm{~m}$ and $-2012 \pm 57 \mathrm{~m}$ in 1984 and 2008 respectively(Fig. S9).Although the surface speed of Fisher Glacier gradually increased since2008 and the surge initiated in 2013,the terminus of Fisher Glacierreceded $-536 \pm 57 \mathrm{~m}$ between 2008 and 2014. The 
surge advancebetween 2014 and 2016 amounted to $+1356 \pm 29 \mathrm{~m}$ (Supplementary Table S4).The frontal lake area increased from $0.54 \mathrm{~km}^{2}$ to $2.8 \mathrm{~km}^{2}$ between 1984 and 2010 and increased further to $3.2 \mathrm{~km}^{2}$ until 2014. Due to the advancing terminus the like size reduced by $50 \%$, to $1.6 \mathrm{~km}^{2}$, between 2014 and 2016 (Supplementary Table S8).

\section{Discussion}

To the best of our knowledge, this study presents the first detailed surge assessment of Klutlan (19902019) and Fisher (1984-2019) glaciers using surface displacement and elevation change. Altena et al., (2019) reported partial surge dynamics of Fisher and Klutlan glaciers based on surface velocity using GoLIVEdata. However, this data missed before and after surge conditions as this data coverage used only from 2013 to 2018. Also, two surge peaks $\left(6.2 \mathrm{~m} \mathrm{~d}^{-1}\right.$ and $\left.\sim 5 \mathrm{~m} \mathrm{~d}^{-1}\right)$ of Klutlan Glacier were observed in the present study but Altena et al., (2019) reportedonly one peak surge $\left(4 \mathrm{~m} \mathrm{~d}^{-1}\right)$. This difference can be attributed to cloud cover, shadow and snow conditions in Landsat OLI images that were used for generation of GoLIVE data. Therefore, this coarse resolution dataset $(\sim 300 \mathrm{~m})$ alone can fail to track the rapid change in surface velocity (i.e., acceleration and deceleration), which is an important component to understand the surge mechanism. Our study filled such gaps in OLI images (16 days revisit) using Sentinel (05 days revisit)images to track the rapid change insurface displacement.

Several previous studies in Alaska and Yukon suggests that most of the surges are hydrologically controlled such as Variegated, Walsh, Lowell, Tweedsmuir, Donjek, Bering,Trapridge and Steele glaciers (Post, 1966; Stanley, 1969; Kamb et al., 1985; Clarke and Holdsworth, 2002; Frappé and Clarke, 2007; Burgess et al., 2012; Bevington and Copland, 2014; Abe and Furuya, 2015; Wychen et al., 2018; Kochtitzky et al., 2019; Fu and Zhou, 2020). The hydrologically driven surges are associated with the restructuring of subglacial drainage of temperate glaciers from low pressures effective conduits to high pressure distributed channels. Such surgesare largely reported in the Alaskan region and are generally characterized by no pre-surge acceleration, short active phase (1-2 years),abrupt surge initiation and termination(Kamb et al., 1985; Kamb and Engelhardt, 1987). On the contrary, the thermal switch mechanism is related to the transition from mainly cold-based ice in quiescence, to warm-based ice in the surgephase. Such surgesusually exhibit lengthy pre-surge acceleration,the gradual increase in surface displacement, long surge phase and gradual termination. Such surges are mainly observed in the Svalbard region (Monacobreen Glacier)(Murray et al., 2003). In the present study, Klutlan Glacier has shown lengthy active phase (seven years), slow termination and lacking pre-surge acceleration thatcompletely differs to hydrologically controlled surgesbutpartially resemblessurges observed in Svalbard. Fisher Glacier exhibits lengthy pre-surge acceleration (six years), long active phase (three years) and gradual termination which are partly similar to Svalbard-type surges. The main difference between the Fisher Glacier and Svalbard-type surge glacier is the variation in speed of surface displacement during the quiescent phase. Svalbard-type surge glaciers have very slow surface displacement during the quiescent phasesuch as Monacobreen $\left(0.008 \mathrm{~m} \mathrm{~d}^{-1}\right)$ and Bakaninbreen $\left(0.001 \mathrm{~m} \mathrm{~d}^{-1}\right)$, buthighspeed of surface displacement $\left(<0.10 \mathrm{~m} \mathrm{~d}^{-1} \pm 0.04 \mathrm{~m} \mathrm{~d}^{-1}\right)$ was observed on Fisher Glacier (Murray et al., 2003). 
The active phase (six years) of Klutlan Glacier is longer than other known surge-type glaciers in White and Alsek river basins (e.g., Fisher, Steele, Donjeck, Walsh glaciers) except Trapridge Glacier (twenty years) (Table 2). The Fisher Glacier has a lengthy pre-surge acceleration (six years). No other known surge-type glacier in this region has shown such pre-surge acceleration (e.g.,Klutlan, Donjek, Lowell, Tweedsmuir, Walsh and Steele glaciers). The very slow surge termination (six years) of Trapridge Glacier and quick termination of surges on Lowell (three months), and Walsh glaciers (less than two months) is in contrast with gradual surge termination (one year) of Klutlan and Fisher glaciers. However, the duration of gradual surge termination on Klutlan and Fisher glaciers are comparable withthe surge termination (one year) of Donjeck Glacier in 2012-14. The maximum surface flow speedof Klutlan $\left(6.2 \mathrm{~m} \mathrm{~d}^{-1}\right)$ and Fisher $\left(7 \mathrm{~m} \mathrm{~d}^{-1}\right)$ glacier are smaller than Steele Glacier $\left(24 \mathrm{~m} \mathrm{~d}^{-1}\right)$, Walsh Glacier $\left(14 \mathrm{~m} \mathrm{~d}^{-1}\right)$ and Lowell Glacier $\left(10.2 \mathrm{~m} \mathrm{~d}^{-1}\right)$, but these are two times greater than Donjek Glacier $\left(3.2 \mathrm{~m} \mathrm{~d}^{-1}\right)$ and equal to Tweedsmuir Glacier $\left(6 \mathrm{~m} \mathrm{~d}^{-1}\right)$ (Table 2). The exact cause for the difference in surface displacement is unknown but mainly influenced by topography, amount of meltwater and ice mass. We observed the DBL on Klutlan and Fisher glaciers moved $\sim 16$ and $\sim 3 \mathrm{~km}$ down-glacier during surge but the location of DBL did not change during the recent surge (2012-2014) on Donjeck Glacier (Kochtitzky et al., 2019).The previous study (Clarke and Holdsworth, 2002) suggests that Fisher Glacier last surged in 1970 and the present study observed that recently this glacier surged in 2013. The surge of Klutlan Glacier began in 1961 and terminated in 1963 (Clarke and Holdsworth, 2002) whereas recent surged initiated in 2013. Therefore, repeat surge intervals of Fisher and Klutlan glacier are43 and 52 years respectively.

\section{Conclusions}

In this study,a thorough investigation of recent surges of Klutlan and Fisher glaciers was conducted in St. Elias Mountain, North America. We estimated spatio-temporal variability in surface displacement using the longest Landsat programme (TM, ETM + and OLI) and Sentinel2 scenes while ASTER DEMs were used to determine surface elevation changes. The surge of Klutlan and Fisher glaciers started in 2013.The peak surface displacements on both Klutlan $\left(6.2 \mathrm{~m} \mathrm{~d}^{-1}\right.$ and $\left.5 \mathrm{~m} \mathrm{~d}^{-1}\right)$ and Fisher $\left(\sim 7 \mathrm{~m} \mathrm{~d}^{-1}\right)$ glaciers were observed during summer of 2016-2018 and 2015 respectively. During $2019-2002$, the reservoir zone of Klutlan Glacier maximum thinned by $-65 \pm 33 \mathrm{~m}$ while the lower receiving zone (near terminus)gained maximum thickness by $+31 \pm 40 \mathrm{~m}$. The reservoir zone of Fisher Glacier maximum lowered by $-60 \pm 22 \mathrm{~m}$ while the terminus gained $+80 \pm 22 \mathrm{~m}$ ice mass between 2019 and 2003. The surge characteristics of Klutlan and Fisher glaciers are completely different from characteristics of hydrologically controlled surges butresemblepartly with the thermally controlled surge. The repeat surge interval of Fisher and Klutlan glacier is 43 and 52 years respectively.

\section{Declarations}

Acknowledgements 
The authors are thankful to NASA/USGS to provided ASTER data for GLIMS (Global Land Ice Measurements from Space) at no cost.

\section{References}

1. Abe, T. and Furuya, M., (2015) Winter speed-up of quiescent surge-type glaciers in Yukon, Canada. The Cryosphere, 9(3), pp.1183-1190.

2. Altena, B., Scambos, T., Fahnestock, M. and Kääb, A., (2019) Extracting recent short-term glacier velocity evolution over southern Alaska and the Yukon from a large collection of Landsat data. The Cryosphere, 13(3), pp.795-814.

3. Benn, D.I., Fowler, A.C., Hewitt, I. and Sevestre, H., (2019) A general theory of glacier surges. Journal of Glaciology, 65(253).

4. Bevington, A. and Copland, L., (2014) Characteristics of the last five surges of Lowell Glacier, Yukon, Canada, since 1948. Journal of Glaciology, 60 (219), pp.113-123.

5. Bhambri, R., Hewitt, K., Kawishwar, P. and Pratap, B., (2017) Surge-type and surge-modified glaciers in the Karakoram. Scientific reports, 7(1), pp.1-14.

6. Bhambri, R., Hewitt, K., Kawishwar, P., Kumar, A., Verma, A., Tiwari, S. and Misra, A., (2019) Ice-dams, outburst floods, and movement heterogeneity of glaciers, Karakoram. Global and Planetary Change, 180, pp.100-116.

7. Bjørk, A.A., Kjær, K.H., Korsgaard, N.J., Khan, S.A., Kjeldsen, K.K., Andresen, C.S., Box, J.E., Larsen, N.K. and Funder, S., (2012) An aerial view of 80 years of climate-related glacier fluctuations in southeast Greenland. Nature Geoscience, 5(6), pp.427-432.

8. Buades, A., Coll, B. and Morel, J.M., (2006) The staircasing effect in neighborhood filters and its solution. IEEE transactions on Image Processing, 15(6), pp.1499-1505.

9. Burgess, E.W., Forster, R.R., Larsen, C.F. and Braun, M., (2012) Surge dynamics on Bering Glacier, Alaska, in 2008-2011. The Cryosphere, 6(6), pp.1251-1262.

10. Clague, J.J. and Rampton, V.N., (1982) Neoglacial Lake Alsek. Canadian Journal of Earth Sciences, 19(1), pp.94-117.

11. CLARKE, G.K. and HOLDSWORTH, G., (2002) Glaciers of the St. Elias mountains. US Geological Survey professional paper, (1386J).

12. Clarke, G.K., Schmok, J.P., Ommanney, C.S.L. and Collins, S.G., (1986) Characteristics of surge type glaciers. Journal of Geophysical Research: Solid Earth, 91(B7), pp.7165-7180.

13. Crompton, J.W., Flowers, G.E. and Stead, D., (2018) Bedrock fracture characteristics as a possible control on the distribution of surge type glaciers. Journal of Geophysical Research: Earth Surface, 123(5), pp.853-873.

14. Dolgoushin, L.D. and Osipova, G.B., (1975) Glacier surges and the problem of their forecasting. IAHS Publ, 104, pp.292-304. 
15. Driscoll Jr, F.G., 1980. Formation of the neoglacial surge moraines of the Klutlan Glacier, Yukon Territory, Canada. Quaternary Research, 14(1), pp.19-30.

16. Fatland, D.R. and Lingle, C.S., 2002. InSAR observations of the 1993-95 Bering Glacier (Alaska, USA) surge and a surge hypothesis. Journal of Glaciology, 48(162), pp.439-451.

17. Fleming, M.D., Chapin III, F.S., Cramer, W., Hufford, G.L. and Serreze, M.C., 2000. Geographic patterns and dynamics of Alaskan climate interpolated from a sparse station record. Global Change Biology, 6(S1), pp.49-58.

18. Fowler, A.C., Murray, T. and Ng, F.S.L., 2001. Thermally controlled glacier surging. Journal of Glaciology, 47(159), pp.527-538.

19. Frappé, T.P. and Clarke, G.K., 2007. Slow surge of Trapridge Glacier, Yukon Territory, Canada. Journal of Geophysical Research: Earth Surface, 112(F3).

20. Fu, X. and Zhou, J., 2020. Recent Surge Behaviour of Walsh Glacier Revealed by Remote Sensing Data. Sensors, 20(3), p.716.

21. Gardelle, J., Berthier, E., Arnaud, Y. and Kääb, A., 2013. Region-wide glacier mass balances over the Pamir-Karakoram-Himalaya during 1999-2011. The Cryosphere, 7(4), pp.1263-1286.

22. Goossens, B., Luong, H., Pizurica, A. and Philips, W., 2008. An improved non-local denoising algorithm. In 2008 International Workshop on Local and Non-Local Approximation in Image Processing (LNLA 2008) (pp. 143-156).

23. Hall, D.K., Bayr, K.J., Schöner, W., Bindschadler, R.A. and Chien, J.Y., 2003. Consideration of the errors inherent in mapping historical glacier positions in Austria from the ground and space (1893-2001). Remote Sensing of Environment, 86(4), pp.566-577.

24. Heid, T. and Kääb, A., 2012. Evaluation of existing image matching methods for deriving glacier surface displacements globally from optical satellite imagery. Remote Sensing of Environment, 118, pp.339-355.

25. Jiskoot, H., 2011. Glacier surging. Encyclopedia of Snow, Ice and Glaciers, pp.415-428.

26. Jiskoot, H., Boyle, P. and Murray, T., 1998. The incidence of glacier surging in Svalbard: evidence from multivariate statistics. Computers \& Geosciences, 24(4), pp.387-399.

27. Kääb, A. and Vollmer, M., 2000. Surface geometry, thickness changes and flow fields on creeping mountain permafrost: automatic extraction by digital image analysis. Permafrost and Periglacial Processes, 11(4), pp.315-326.

28. Kamb, B. and Engelhardt, H., 1987. Waves of accelerated motion in a glacier approaching surge: the mini-surges of Variegated Glacier, Alaska, USA. Journal of Glaciology, 33(113), pp.27-46.

29. Kamb, B., Raymond, C. F., Harrison, W. D., Engelhardt, H., Echelmeyer, K. A., Humphrey, N., Brugman, M. M., \& Pfeffer, T., 1985. Glacier surge mechanism: 1982-1983 surge of variegated glacier, Alaska. Science (New York, N.Y.), 227(4686), pp.469-479.

30. Kargel, J.S., Abrams, M.J., Bishop, M.P., Bush, A., Hamilton, G., Jiskoot, H., Kääb, A., Kieffer, H.H., Lee, E.M., Paul, F. and Rau, F., 2005. Multispectral imaging contributions to global land ice measurements 
from space. Remote sensing of environment, 99(1-2), pp.187-219.

31. Kochtitzky, W., Jiskoot, H., Copland, L., Enderlin, E., McNabb, R., Kreutz, K. and Main, B., 2019. Terminus advance, kinematics and mass redistribution during eight surges of Donjek Glacier, St. Elias Range, Canada, 1935 to 2016. Journal of Glaciology, 65(252), pp.565-579.

32. Kochtitzky, W., Winski, D., McConnell, E., Kreutz, K., Campbell, S., Enderlin, E.M., Copland, L., Williamson, S., Main, B. and Jiskoot, H., 2020. Climate and surging of Donjek Glacier, Yukon, Canada. Arctic, Antarctic, and Alpine Research, 52(1), pp.264-280.

33. Leprince, S., Barbot, S., Ayoub, F. and Avouac, J.P., 2007. Automatic and precise orthorectification, coregistration, and subpixel correlation of satellite images, application to ground deformation measurements. IEEE Transactions on Geoscience and Remote Sensing, 45(6), pp.1529-1558.

34. Marcus, M.G. and Ragle, R.H., 1970. Snow accumulation in the Icefield Ranges, St. Elias Mountains, Yukon. Arctic and Alpine Research, 2(4), pp.277-292.

35. Meier MF, Post AS (1969) What are glacier surges? Canadian Journal of Earth Sciences 6(4): 807817.

36. Murray, T., Strozzi, T., Luckman, A., Jiskoot, H. and Christakos, P., 2003. Is there a single surge mechanism? Contrasts in dynamics between glacier surges in Svalbard and other regions. Journal of Geophysical Research: Solid Earth, 108(B5), pp.1-15.

37. Nuth, C. and Kääb, A., 2011. Co-registration and bias corrections of satellite elevation data sets for quantifying glacier thickness change. The Cryosphere, 5(1), pp.271-290.

38. Pitte, P., Berthier, E., Masiokas, M.H., Cabot, V., Ruiz, L., Hidalgo, L.F., Gargantini, H. and Zalazar, L., 2016. Geometric evolution of the Horcones Inferior Glacier (Mount Aconcagua, Central Andes) during the 2002-2006 surge. Journal of Geophysical Research: Earth Surface, 121(1), pp.111-127.

39. Post, A., 1966. The recent surge of Walsh glacier, Yukon and Alaska. Journal of Glaciology, 6(45), pp.375-381.

40. Post, A., 1969. Distribution of surging glaciers in western North America. Journal of Glaciology, 8(53), pp.229-240.

41. Quincey, D.J., Glasser, N.F., Cook, S.J. and Luckman, A., 2015. Heterogeneity in Karakoram glacier surges. Journal of Geophysical Research: Earth Surface, 120(7), pp.1288-1300.

42. Rampton, V., 1970. Neoglacial fluctuations of the Natazhat and Klutlan Glaciers, Yukon Territory, Canada. Canadian Journal of Earth Sciences, 7(5), pp.1236-1263.

43. Redpath, T.A.N., Sirguey, P., Fitzsimons, S.J. and Kääb, A., 2013. Accuracy assessment for mapping glacier flow velocity and detecting flow dynamics from ASTER satellite imagery: Tasman Glacier, New Zealand. Remote Sensing of Environment, 133, pp.90-101.

44. RGI Consortium, 2017. Randolph Glacier Inventory (v.6.0): A Dataset of Global Glacier Outlines. Global Land Ice Measurements from Space. RGI Technical Report 1, 1-10.

45. Round, V., Leinss, S., Huss, M., Haemmig, C. and Hajnsek, I., 2017. Surge dynamics and lake outbursts of Kyagar Glacier, Karakoram. The Cryosphere, 11(2), pp.723-739. 
46. Scherler, D., Leprince, S. and Strecker, M.R., 2008. Glacier-surface velocities in alpine terrain from optical satellite imagery-Accuracy improvement and quality assessment. Remote Sensing of Environment, 112(10), pp.3806-3819.

47. Sevestre, H. and Benn, D.I., 2015. Climatic and geometric controls on the global distribution of surgetype glaciers: implications for a unifying model of surging. Journal of Glaciology, 61(228), pp.646662.

48. Stanley, A.D., 1969. Observations of the surge of Steele Glacier, Yukon Territory, Canada. Canadian Journal of Earth Sciences, 6(4), pp.819-830.

49. Van Wychen, W., Copland, L., Jiskoot, H., Gray, L., Sharp, M. and Burgess, D., 2018. Surface velocities of glaciers in Western Canada from speckle-tracking of ALOS PALSAR and RADARSAT-2 data.

Canadian Journal of Remote Sensing, 44(1), pp.57-66.

50. Waechter, A., 2013. Regional Assessment of Glacier Motion in Kluane National Park, Yukon Territory (Doctoral dissertation, Universitéd' Ottawa/University of Ottawa).

\section{Tables}

Table 1 was not provided with this version

Table 2:Surge characteristics of surge-type glaciers in the St Elias Mountains.

\begin{tabular}{|c|c|c|c|c|c|c|c|c|c|}
\hline \multirow[t]{2}{*}{$\begin{array}{l}\text { S. } \\
\text { No. }\end{array}$} & \multirow[t]{2}{*}{ Name of Glacier } & \multicolumn{3}{|c|}{ Duration } & \multicolumn{3}{|c|}{$\begin{array}{c}\text { Maximum surge flow } \\
\text { speed }\end{array}$} & \multirow{2}{*}{$\begin{array}{c}\text { Surge } \\
\text { reoccur } \\
\text { rence } \\
\text { interval } \\
\text { (years) }\end{array}$} & \multirow[t]{2}{*}{ References } \\
\hline & & $\begin{array}{l}\text { Pre-surge } \\
\text { acceleration } \\
\text { (years) }\end{array}$ & $\begin{array}{l}\text { Active } \\
\text { phase } \\
\text { (year) }\end{array}$ & $\begin{array}{l}\text { Terminatio } \\
\text { n (year } / \mathrm{s})\end{array}$ & $\begin{array}{l}\text { No. } \\
\text { of } \\
\text { peak } \\
\text { surg } \\
\text { es }\end{array}$ & $\begin{array}{l}\text { Magnitu } \\
\text { de } \\
\left(\mathrm{m} \mathrm{d}^{-1}\right)\end{array}$ & Year & & \\
\hline \multirow[t]{2}{*}{1} & \multirow[t]{2}{*}{ Klutlan Glacier } & & \multirow[t]{2}{*}{6} & \multirow[t]{2}{*}{$\sim 1$} & \multirow[t]{2}{*}{2} & 6.2 & 2016 & \multirow[t]{2}{*}{$\sim 52$} & \multirow[t]{2}{*}{ Present study } \\
\hline & & & & & & 5 & 2018 & & \\
\hline 2 & Fisher Glacier & 6 & 3 & $\sim 1$ & 1 & 7 & 2015 & $\sim 43$ & Present study \\
\hline 3 & Donjek Glacier & & $<2$ & 1 & 1 & 3.2 & 2013 & $\sim 12$ & Kochtitzky et al.,(2019) \\
\hline 4 & Steele Glacier & & 3 & & 1 & 24 & 1966 & & Stanley, (1969) \\
\hline 5 & $\begin{array}{l}\text { Trapridge } \\
\text { Glacier }\end{array}$ & & 20 & 6 & 1 & 0.1 & 1984 & 40 & Frappé and Clarke, (2007) \\
\hline 6 & Lowell Glacier & & $<2$ & 3 months & 1 & 10.2 & 2010 & $\sim 12-20$ & $\begin{array}{l}\text { Bevington and Copland, } \\
\text { (2014) }\end{array}$ \\
\hline 7 & $\begin{array}{l}\text { Tweedsmuir } \\
\text { Glacier }\end{array}$ & & 1 & & 1 & 6 & 2008 & $20-30$ & $\begin{array}{l}\text { Abe and Furuya, (2015); } \\
\text { Wychen et al.,(2018) }\end{array}$ \\
\hline 8 & Walsh Glacier & & $<2$ & $<2$ months & 1 & 14 & 2016 & $>40$ & Fu and Zhou, (2020) \\
\hline
\end{tabular}




\section{Supplementary Figures And Tables}

Supplementary Figures and Tables are not available with this version. Figures
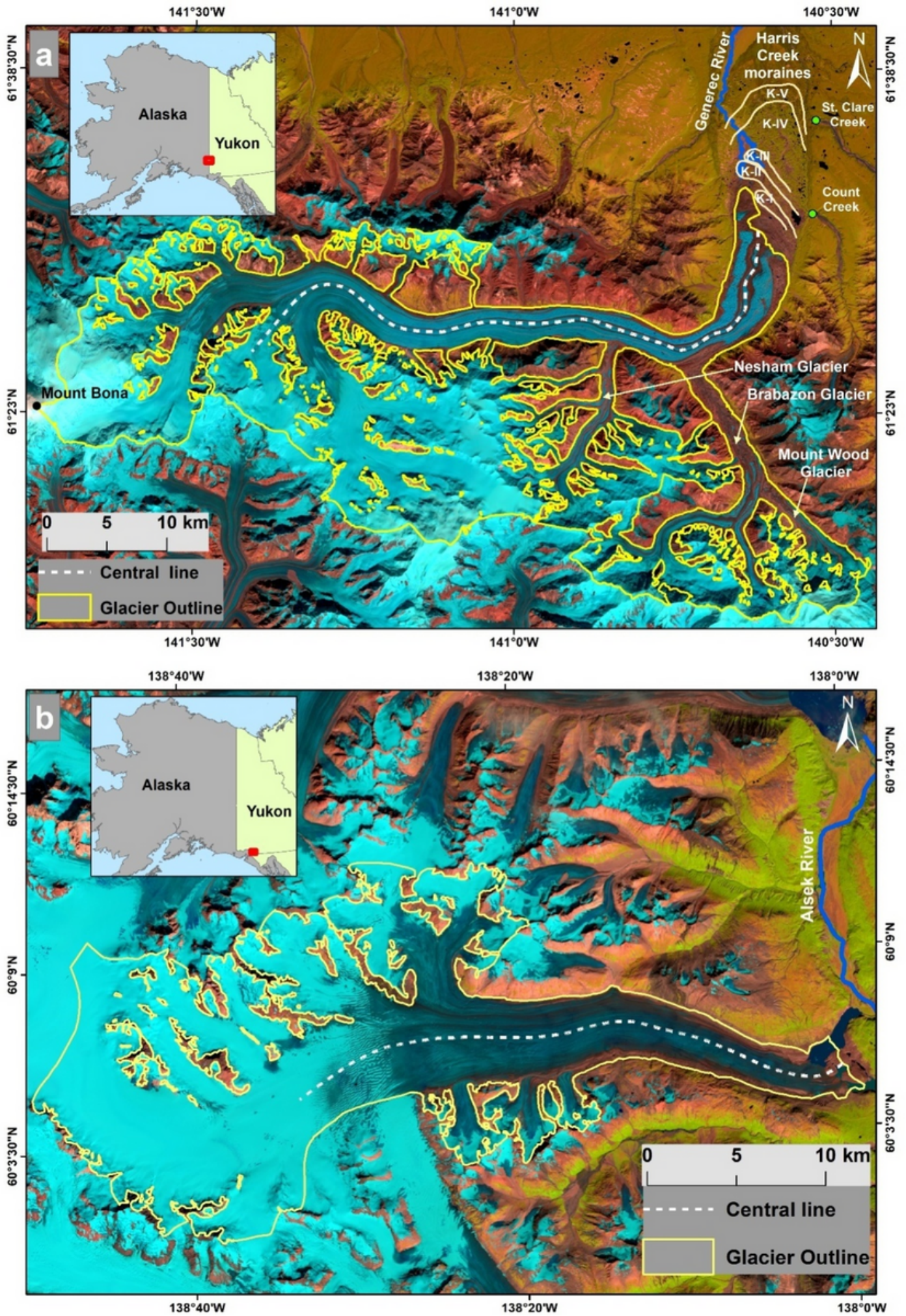

Figure 1 
Overview of the study area: (a) Klutlan Glacier situated at the international divide between Alaska and Yukon. The location of the neoglacial Harris Creek moraines is from Driscoll $\mathrm{Jr}(1980)$. The base image is a Landsat 8 OLI scene (11 August 2013; bands 6-5-4); (b) Fisher Glacier in southwestern Yukon, Canada. The base image is (bands 6-5-4) Landsat 8 OLIscene (13 August 2013).

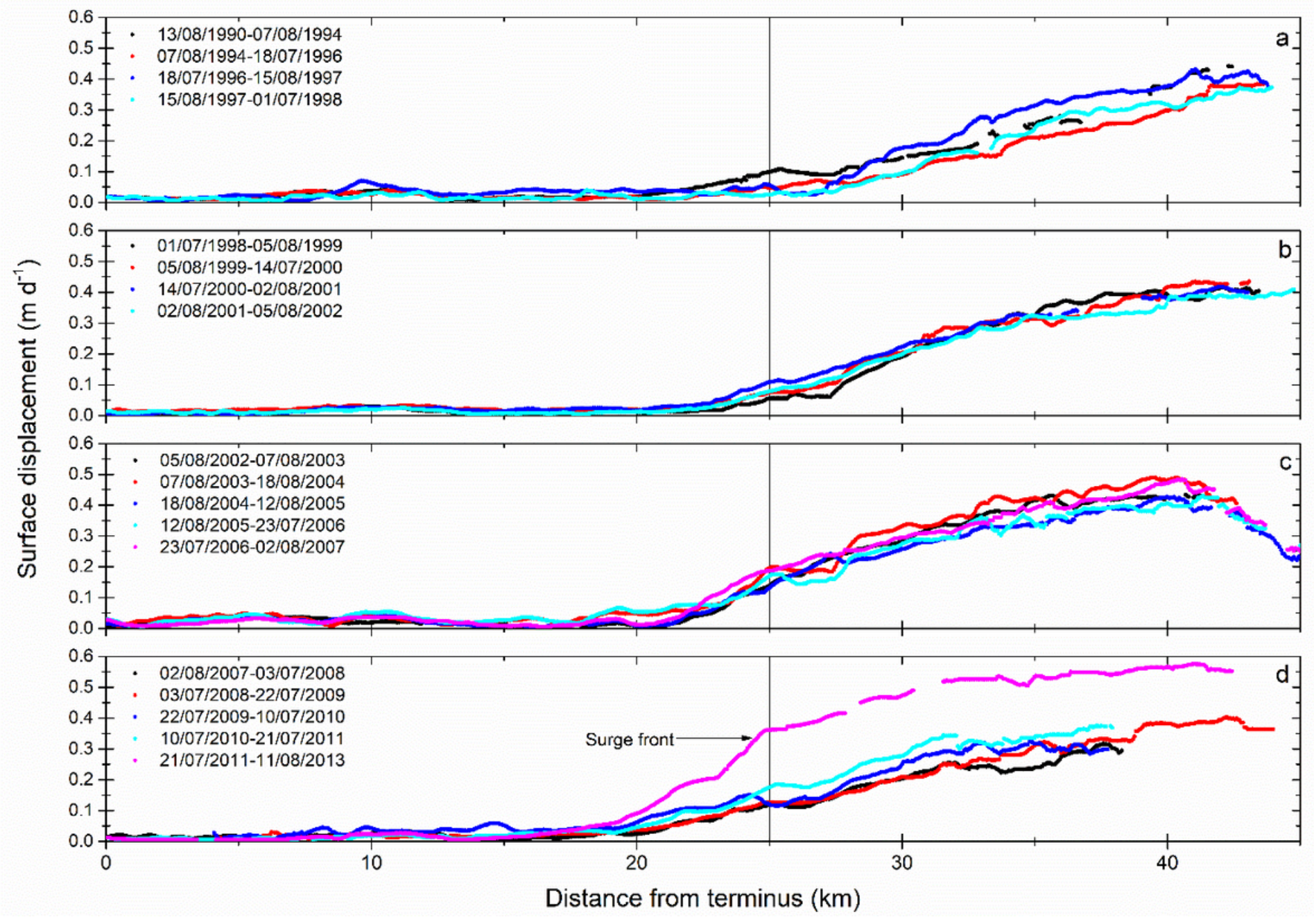

Figure 2

Surface flow speedalong the centreline of Klutlan Glacier between 1990 and 2013calculatedusing COSICORR during 1990-2013 extracted through the central line. 


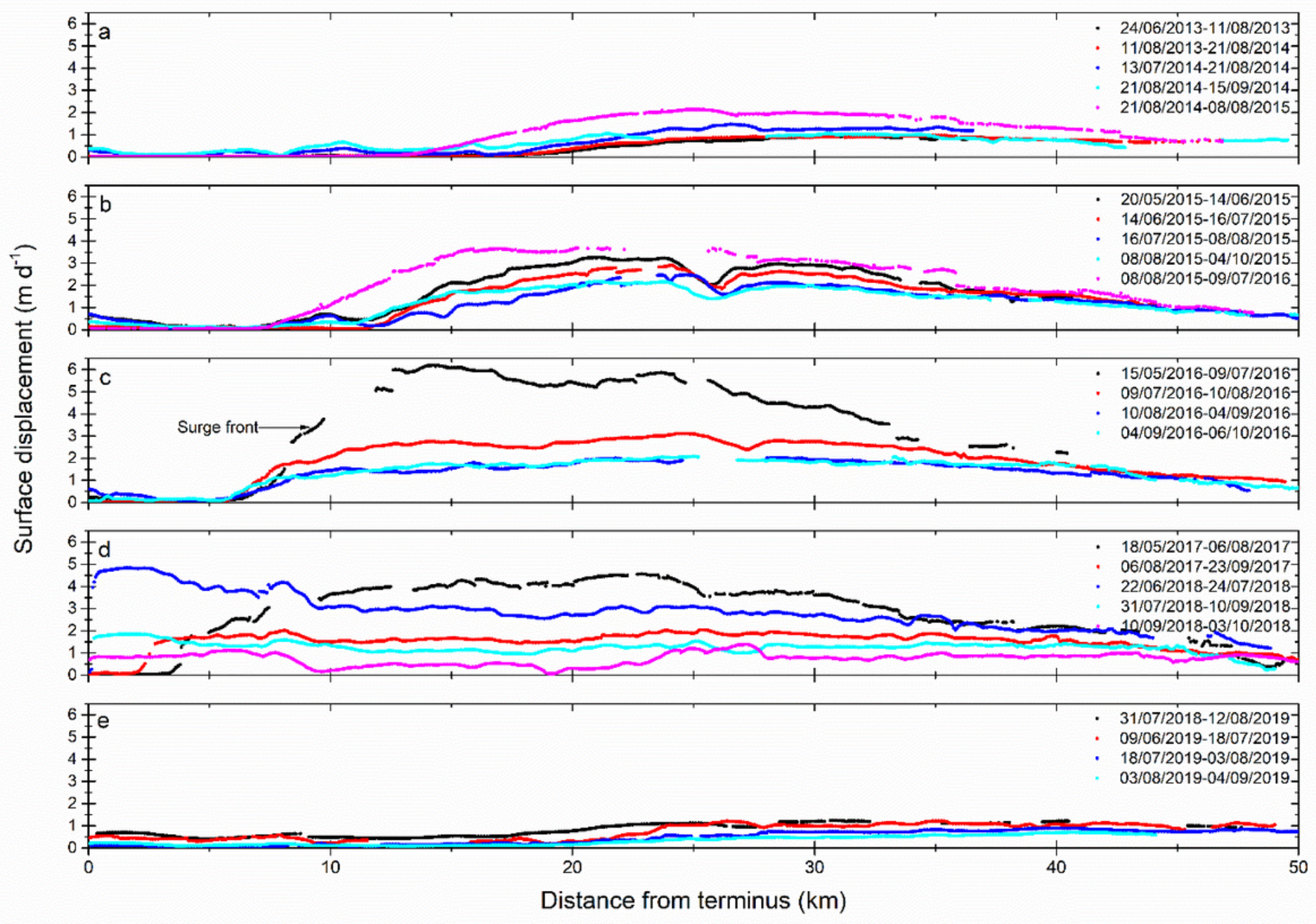

\section{Figure 3}

Surface displacement of Klutlan Glacier estimated using COSI-CORR during the surge phase (2013-2019) extracted through the centre flowline. 


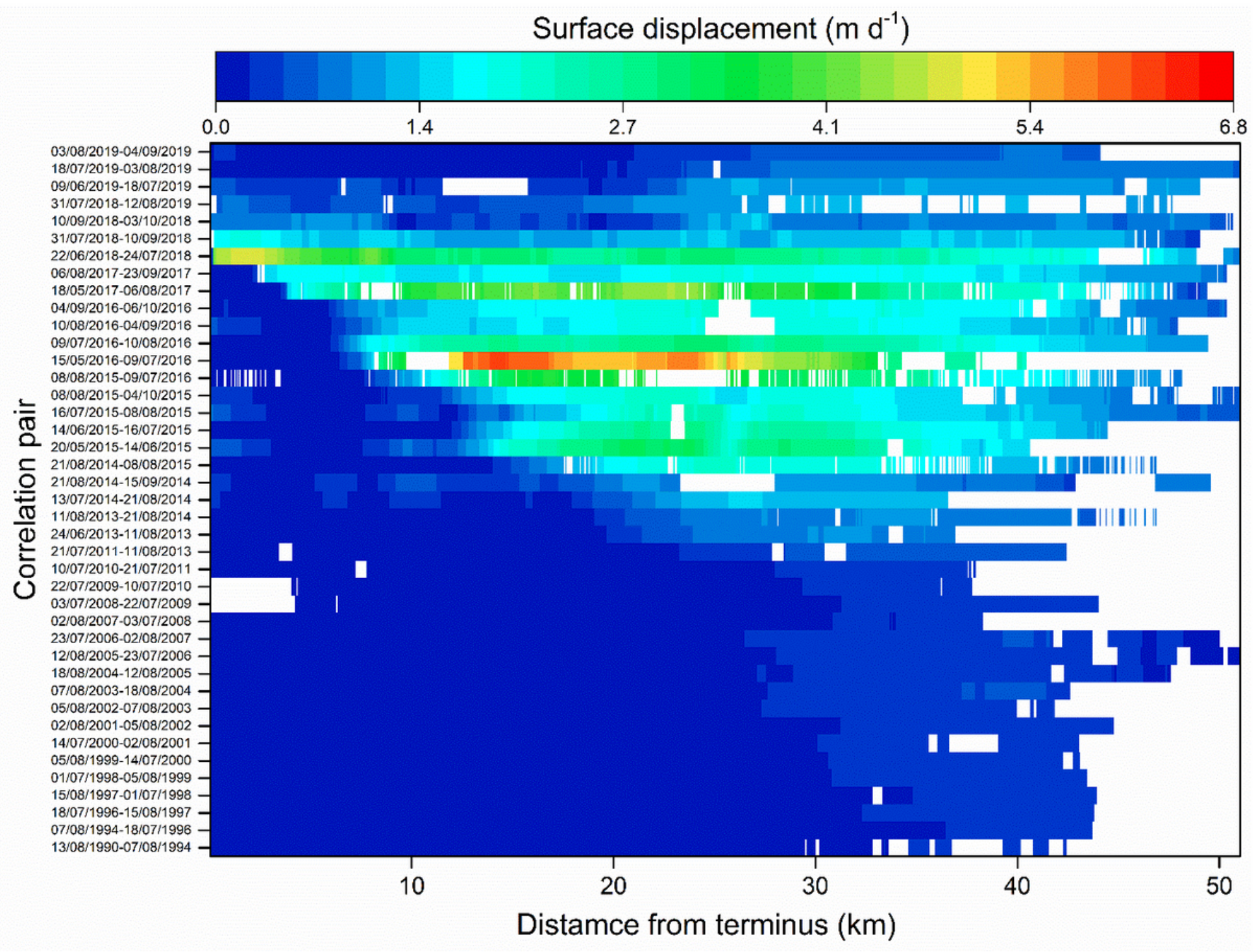

Figure 4

Spatio-temporal pattern of changes in the surface speed of Klutlan Glacier along the central line between 1900 (bottom) and 2019 (top). 

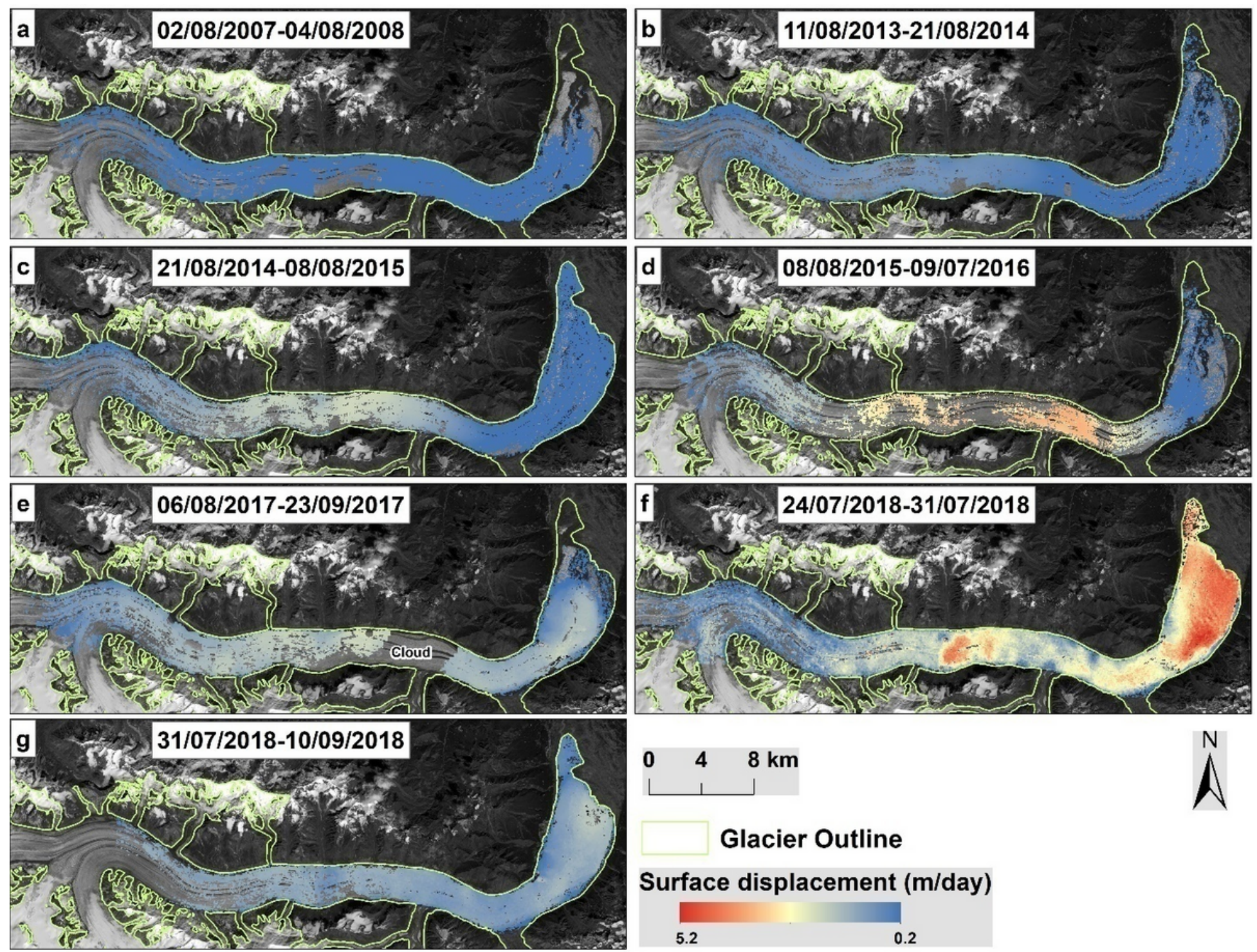

Figure 5

CIAS derived spatio-temporal changes in surface displacementofKlutlan Glacier between 2007 and 2018.Surface displacement maps (a-g) overlaid on Landsat OLI (band 8) image (24 July 2018). 


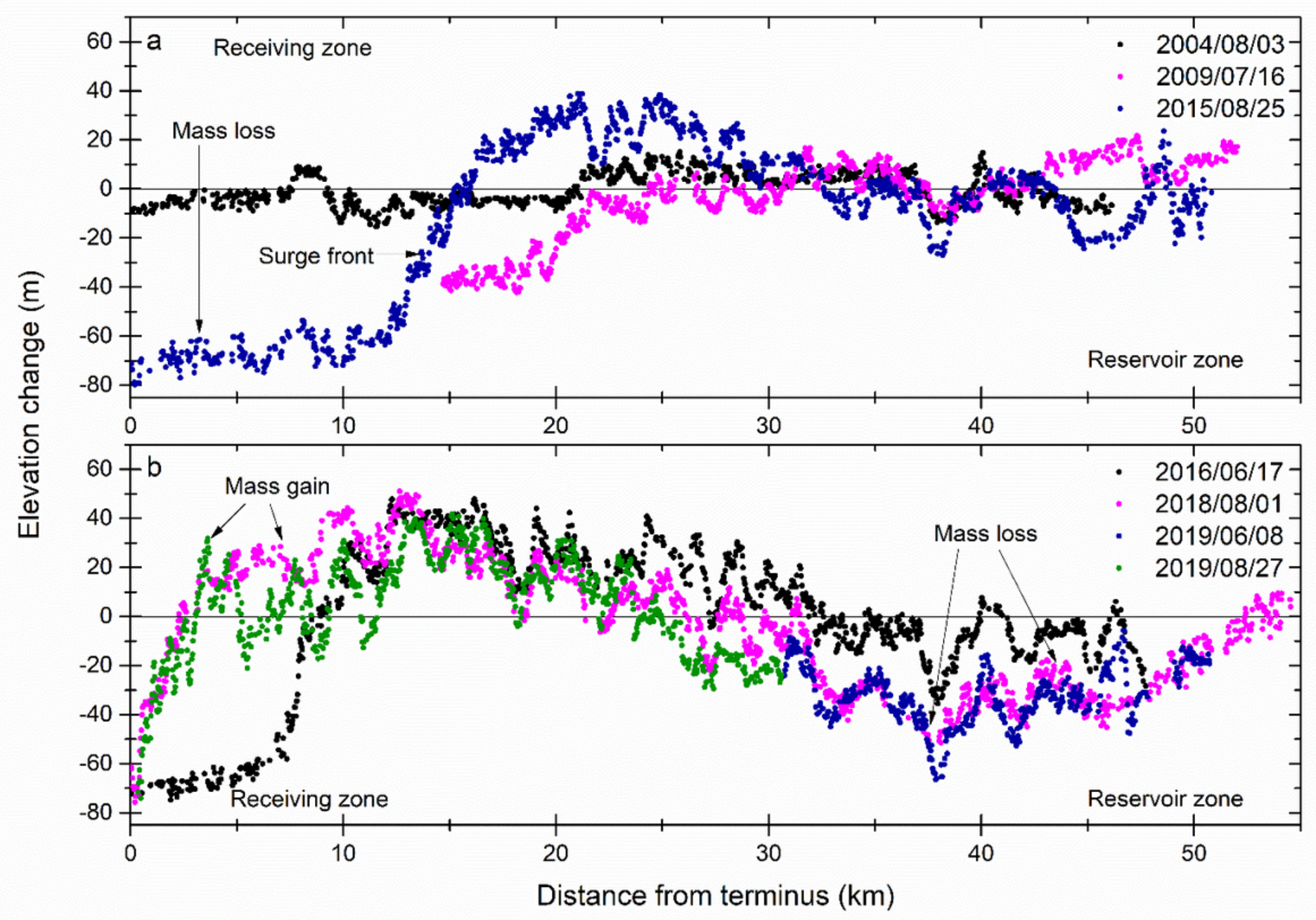

Figure 6

Surface elevation change of Klutlan Glacier extracted from ASTER DEMs differencing. All the ASTER DEMs were subtracted from 2002 ASTER DEM. 

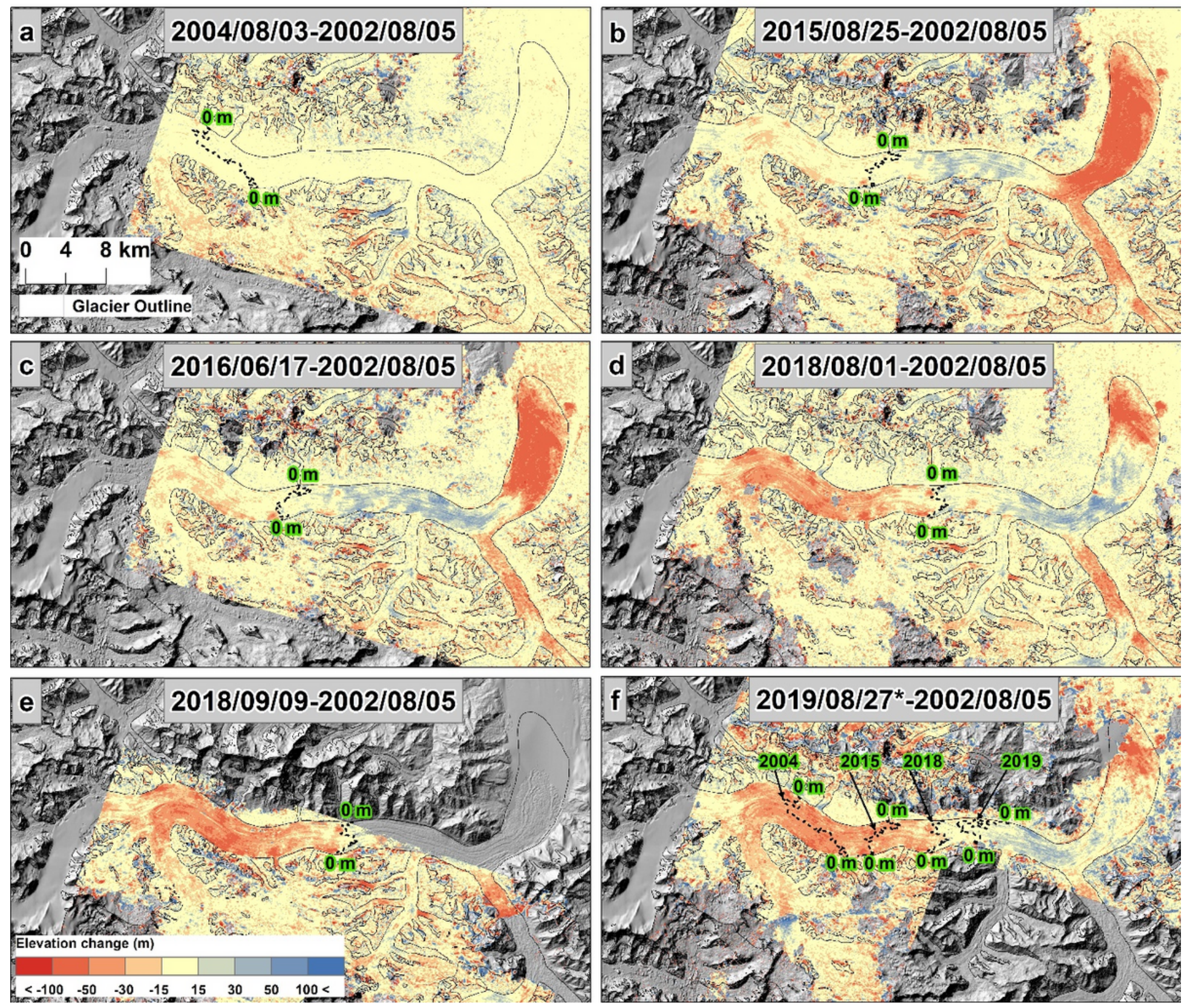

Figure 7

DEM differencing result of Klutlan Glacier using multiple ASTER DEMs after co-registration. The background image is hillshade map ofASTER GDEM $(30 \mathrm{~m})$. Spatio-temporal changes of surface elevation before and after the surge is shown from sub-figure a to $\mathrm{f}$. The black dotted line represents DBL. The sub figfis a combination of $27 / 08 / 2019 *$ and $08 / 06 / 2019$, which are used to coverreceiving zone aswell as reservoir zone. 

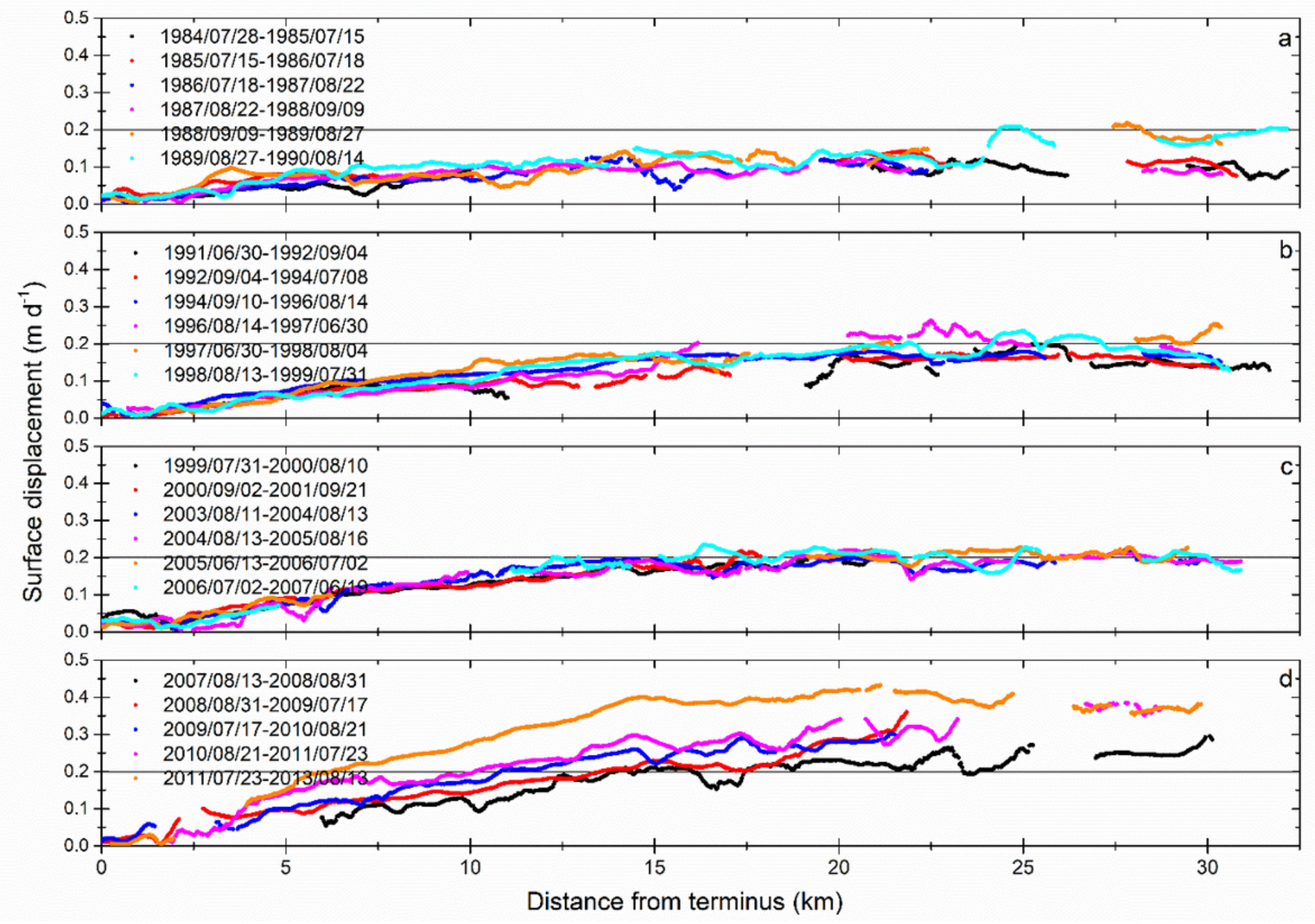

\section{Figure 8}

The evolution of surface displacement on Fisher Glacier measured along the central flow line using COSICORR software during 1984-2013. 


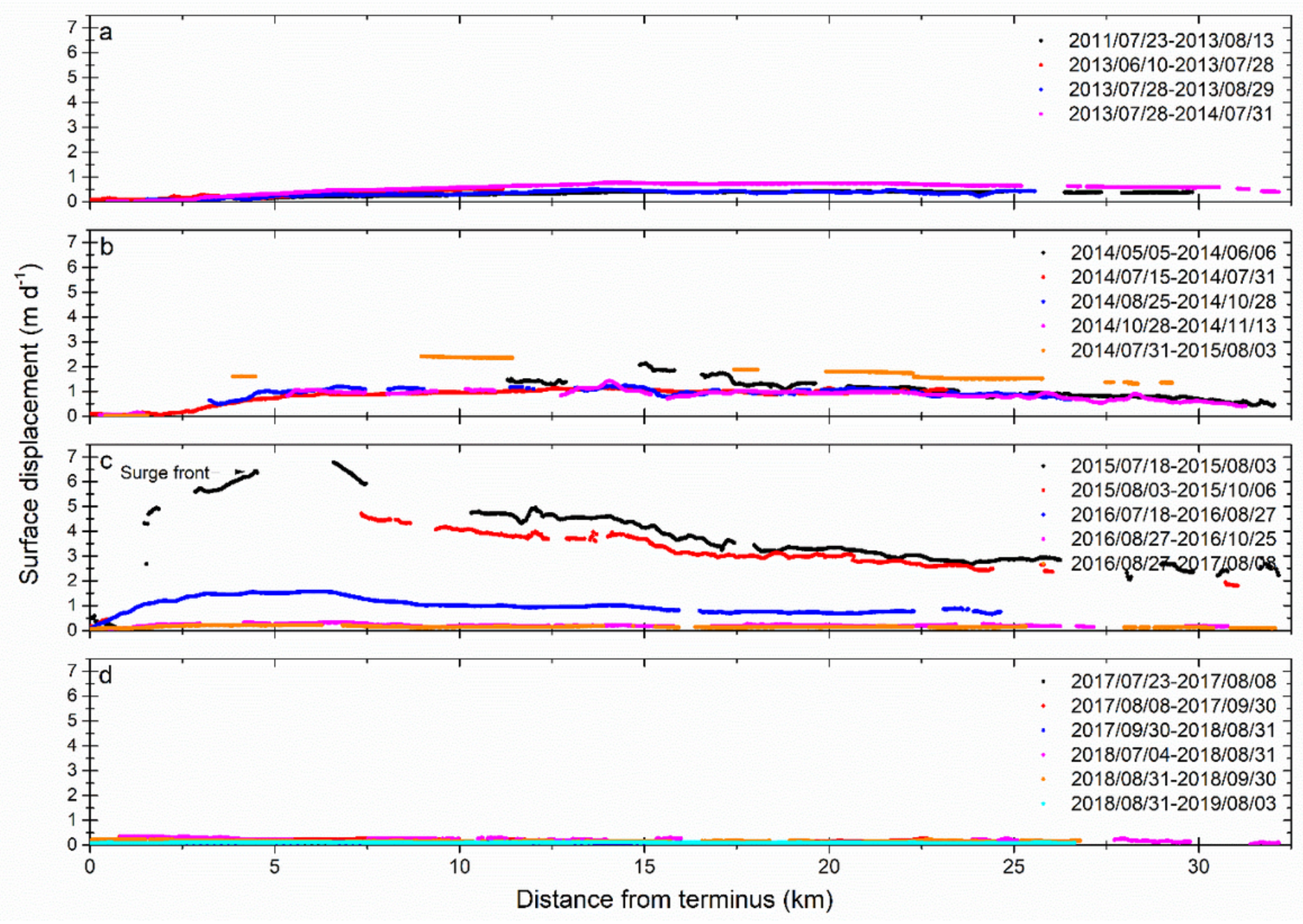

Figure 9

The evolution ofsurface velocity on Fisher Glacier measured along the central flow line through COSICORR softwarefrom2011 to 2019. 
Surface displacement $\left(\mathrm{m} \mathrm{d}^{-1}\right)$
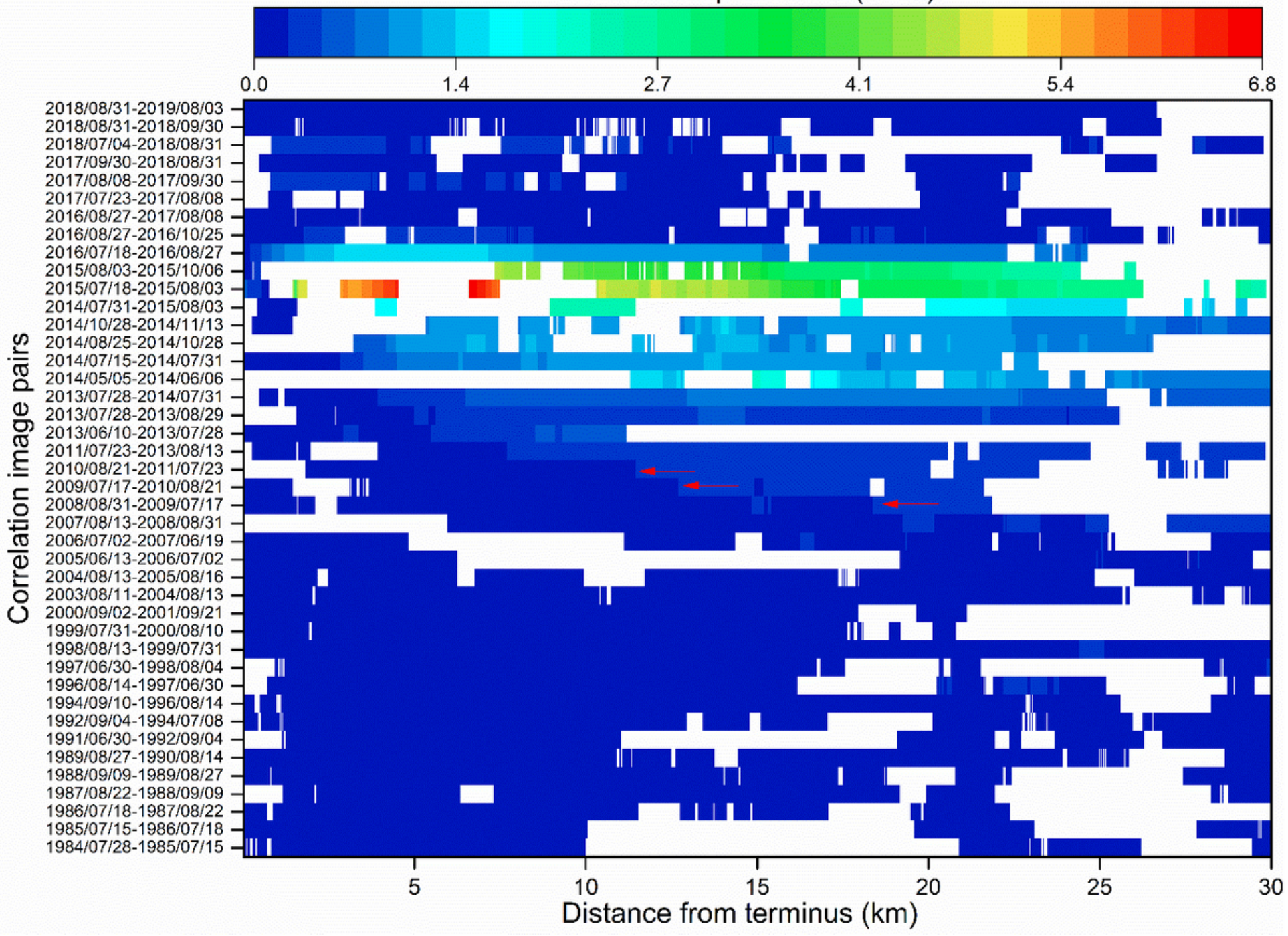

Figure 10

COSI-CORR derived surface displacement of Fisher Glacier from 1984 to 2019. The red arrows indicate changes in surface displacement during the pre-surge acceleration (2007-2013). 


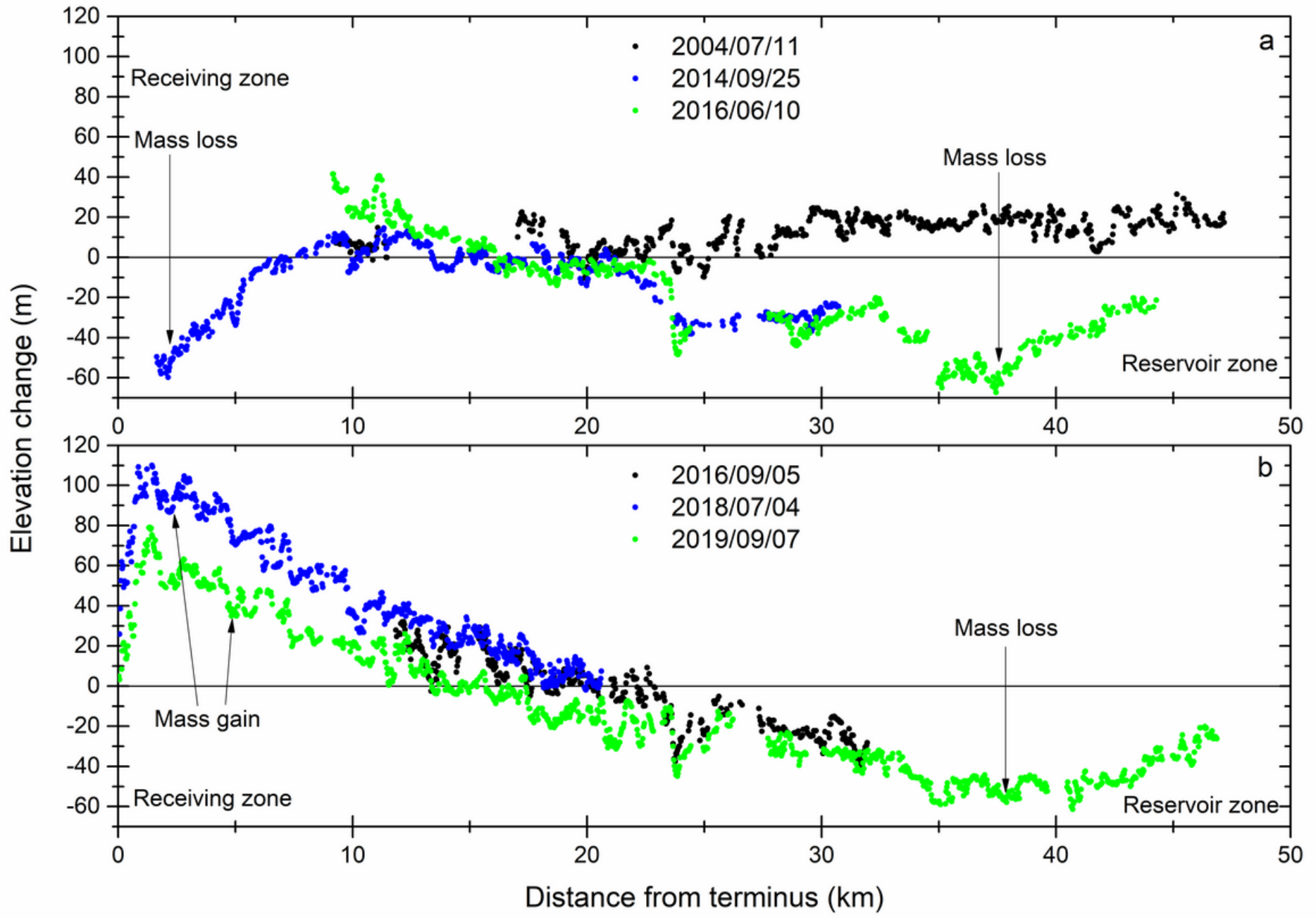

Figure 11

Surface elevation change profile of Fisher Glacier extracted usingdifferencing of ASTER DEMs. 


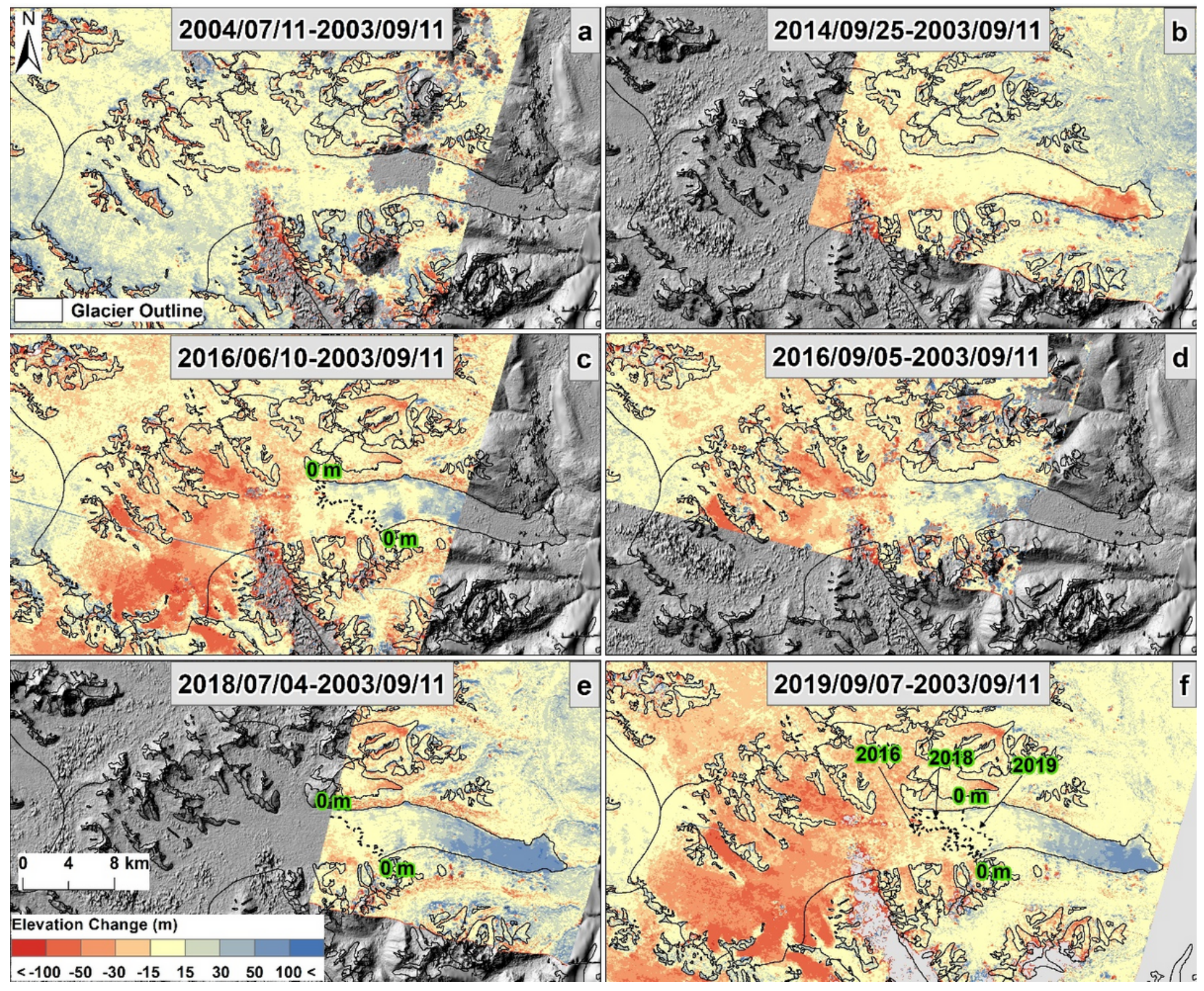

Figure 12

DEM differencing of Fisher Glacier using multiple ASTER DEMs after co-registration. The background hillshade images areASTER GDEM(30m). Spatio-temporal changes of surface elevation before, during and after the surge is shown from a to $f$. The black dotted line from (b) to (f) represents the DBL. 


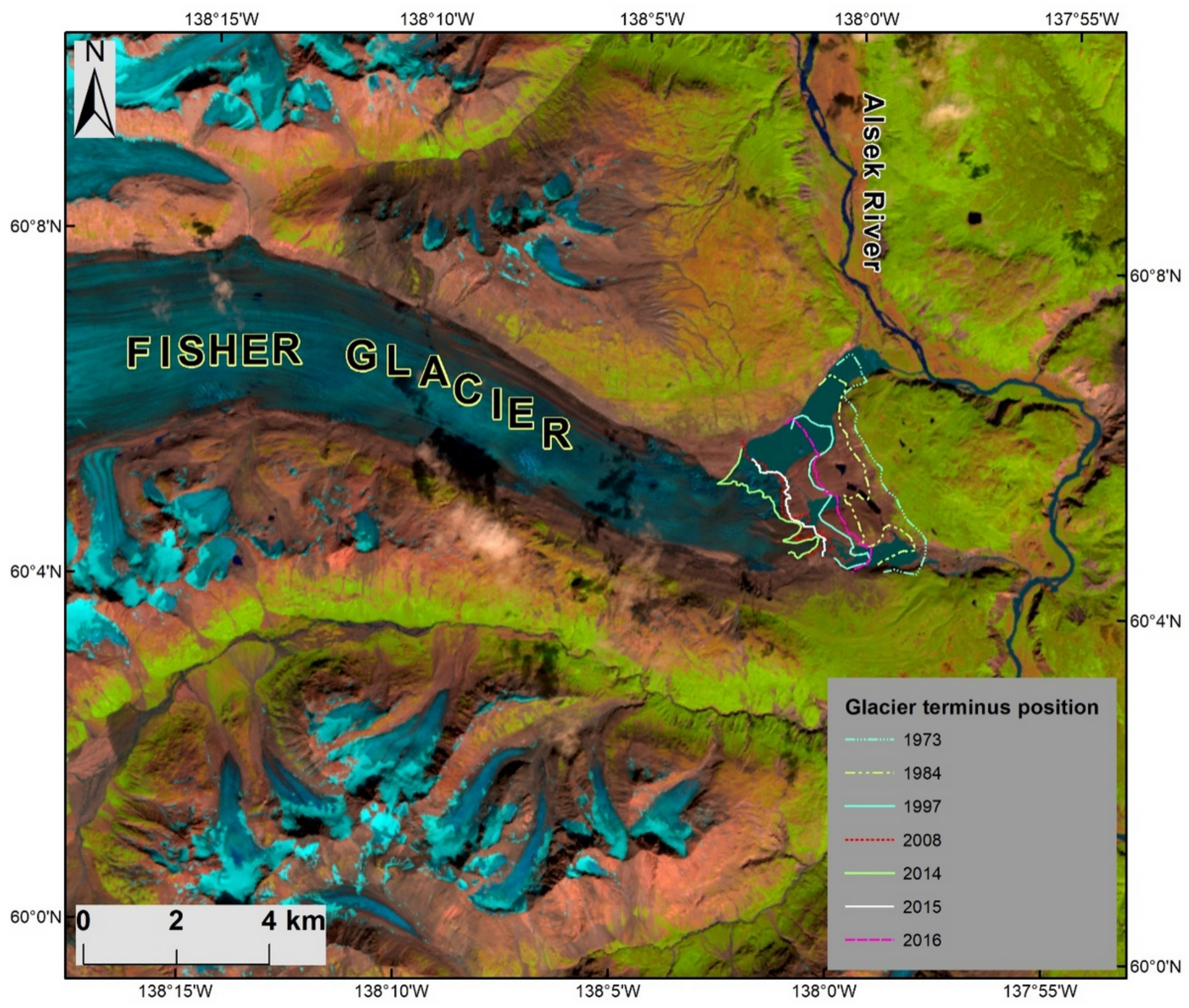

Figure 13

Terminus change of Fisher Glacier from 1973 to 2016. The base image is Landsat OLI (bands 6-5-4) of 03 August 2015. 